\title{
The Case of 'Suspected Adulteress': Reading Numbers 5:11-31 from the Perspective of a Married African Woman
}

\author{
AleXANDER IZUCHUKWU ABASILI (KU LEUVEN)
}

\begin{abstract}
As studies have shown, marital sexual infidelity is attested in every society of the world. ${ }^{\text {I }}$ In African societies, adultery is not only strictly prohibited on social, moral and religious grounds but is also regarded, in some African cultures, as an abomination. This is rooted, among others, in the sacredness of marriage in Africa and the inseparable link between the use of human sexuality in marriage and the generation of new life for the perpetuation of the familylineage and the community. In theory, the ban on adultery applies equally to all married men and women but in praxis, there are some hints of gender injustice against women in observing the ban on adultery. The patriarchal context in some African cultures provides the background for such gender inequality and sexual injustice against women. By using bosadi biblical hermeneutics to interpret the Sotah ritual (Num 5:11-31) - a ritual that is gender-specific, meant only for women accused of adultery - this article condemns the sexual injustice endured by married women in some (African) patriarchal societies and advocates the reading of Num 5:11-31 and other biblical texts containing 'oppressive elements' in a way that is liberating and empowering to the oppressed and marginalised.
\end{abstract}

KEYWORDS: Suspected Adulteress, Num 5:11-31, sexual injustice, gender inequality, patriarchy, adultery, bosadi biblical hermeneutics.

\section{A INTRODUCTION}

Marriage in many African societies is not just a union between two persons (a man and a woman) but also a covenant of affinity between two families, two clans or even between two communities. In addition, the use of human sexuality in marriage is inseparably linked to the well-being not only of the married couple but also of the family, clan and the community. Indeed, among

* Submitted: 28/04/2021; peer-reviewed: 26/06/2021; accepted: 02/08/2021. Alexander Izuchukwu Abasili, "The Case of 'Suspected Adulteress': Reading Num 5:11-31 from the Perspective of a Married African Woman" 34 no. 2 (2021): 385 403. DOI: https://doi.org/10.17159/2312-3621/2021/v34n2a5.

1 Annette Lawson, Adultery: An Analysis of Love and Betrayal (Oxford: Basil Blackwell 1988), 302. 
Africans, the perpetuation and propagation of the lineage ranks highest in use of human sexuality in marriage which for them imbues the human sexuality with great value and sacredness. To prevent abuse, some prohibitions are attached to the use of human sexuality and adultery ranks first among the prohibited sexual transgressions in most African cultures. In theory, the ban on adultery applies equally to all married men and women but in praxis, there are some hints of gender injustice against women in its observance. The patriarchal context of some (African) cultures provides the background for gender inequality and sexual injustice against women. Here, I define patriarchy, as "the structural and ideological system that perpetuates the privileging of hegemonic masculinities. In this system, women and girls have historically, and overwhelmingly, been oppressed, exploited or otherwise disadvantaged."2 Although some progress has been recorded already in fighting gender inequality in African, more needs to be done to challenge gender-based discriminations and sexual injustice against women. The present article, therefore, condemns the sexual injustice still endured by married women in some (African) patriarchal societies and advocates the reading of Num 5:11-31 (the Sotah ritual) and other biblical texts containing 'oppressive elements' in a way that is liberating and empowering to the oppressed and marginalised. To date, the Bible as the "Word of God" plays a vital role in the life of many Africans and its liberating and transforming power against oppression and injustice should be underlined and maximised.

For the contextual study of the Sotah ritual (Num 5:11-33), I have opted for the African Biblical Hermeneutics, an approach championed by Prof David Tuesday Adamo, whose erudite scholarship is being honoured in this special issue of OTE. Adamo describes "African Biblical Hermeneutics" as an approach that makes the "African social-cultural context a subject of interpretation." It is "the re-reading of the scripture from a premeditatedly Afrocentric perspective." "In a sense, African Biblical Hermeneutics is an umbrella name for various strands of African liberational and contextual biblical approaches. For the purpose of this study, I will narrow my use of African Biblical Hermeneutics to the Bosadi Critical Approach as described by

2 Ricardo Fal-Dutra Santos, "Challenging Patriarchy: Gender Equality and Humanitarian Principles," equality-humanitarian-principles/.

3 David T. Adamo, "The Task and Distinctiveness," Old Testament Essays 28/1 (2015): 31-52; David T. Adamo, "What Is African Biblical Hermeneutics?" Black Theology: An International Journal 13/1 (2015): 59-72. See also David Tuesday Adamo, "Reading Psalm 35 in Africa (Yoruba) Perspective," Old Testament Essays 32/3 (2019): 936-955 (938). 
Madipoane Masenya. ${ }^{4}$ Bosadi is an African woman's liberation hermeneutic; an approach that is at the intersection of feminism and womanism. Apart from underlining the positive or liberatory elements of the African culture, the bosadi approach does acknowledge the existence of some oppressive aspects of African cultures..$^{5}$ Particularly interesting for my reading is its emphasis on the liberation of African women from some oppressive elements in African context using the transforming power of the Bible. ${ }^{6}$ Thus, African women under various forms of oppression are its clients. The bosadi critical approach advocates for a balanced approach to both the contexts of the biblical text and the context of the interpreter in order to avoid eisegesis.

This article, using bosadi biblical hermeneutics, will denounce both the oppressive aspects of Igbo-African culture and the gender injustice against women seen in the Sotah ritual (Num 5:11-33). It does this by identifying both the 'inclusive' and 'oppressive' dimensions of the Sotah ritual. While it condemns the 'oppressive and subjugating' elements of the ritual, it will underline and maximise the liberating and inclusive elements of the ritual as instruments of empowerment and liberation of women from injustice and subjugation. Beyond the Sotah ritual (Num 5:11-33), this article advocates for the reading and interpretation of similar 'oppressive' biblical texts in ways that are liberating and empowering to the oppressed while condemning the unjust elements. ${ }^{7}$ Even though the Bible is the "Word of God," it is written in a human language and context and it, therefore, contains some imperfections and oppressive elements.

Using the bosadi critical approach (as my hermeneutical lens), combined with narrative analysis (as my exegetical method) ${ }^{8}$ I will read the Sotah ritual through the standpoint of a married African woman. ${ }^{9}$

$4 \quad$ For further understanding of the bosadi critical approach, see Madipoane Masenya, How Worthy Is the Woman of Worth? Rereading Proverbs 31:10-31 (New York: Peter Lang, 2004), 9, 11, 12, 25.

5 Adamo, "Reading Psalm 35 in Africa (Yoruba) Perspective," 938.

6 Madipoane, How Worthy Is the Woman of Worth, 9, 11, 12, 25.

7 Masenya notes that due to the existence of some intrinsically oppressive texts in the Bible, "the bosadi concept is somewhat cautious about the notion of the Bible as "Word of God." Though the authority of the Bible is acknowledged in essence, particularly since the Bible proclaims life, abundant life -righteousness, love, justice, peace and obedience, it is not taken for granted." See Madipoane Masenya, "Struggling to Find "Africa" in South Africa: The Bosadi (Womanhood) Approach to the Bible," SBL Forum, n.p., http://sbl-site.org/Article.aspx?ArticleID=402.

8 Narrative Analysis, as used here, is a biblical interpretative method that focuses on the axis of communication between the reader and the author through the eyes of the reader. In the words of Marguerat and Bourquin, "narrative criticism is primarily oriented neither on the author nor on the message, but on the reader: it has in view the effect of the narrative on the readers and the way in which the text makes them 
By embarking on a contextual reading of Num 5:11-33 with the IgboNigerian culture as a case study, this article uses the case of 'suspected adulteress' descriptively to underline similar injustices suffered by married women in some patriarchal African contexts and makes a clarion call for gender equality and sexual justice among married couples in those contexts. To avoid being too general about the African context in this essay, I will focus on the Igbo-Nigerian culture, as a case study. ${ }^{10}$ The analogy between the ordeal endured by the Sotah and the sexual injustice experienced by an Igbo (Nigerian) woman is only descriptive and non-essential. The immense separation in time, space and context between the Hebrew biblical culture and the contemporary Igbo society discourages essential similarity between them.

We now begin a critical analysis of Num 5:11-31 in view of its contextual implications.

cooperate in deciphering the meaning." Daniel Marguerat and Yvan Bourquin, How to Read the Bible: An Introduction to Narrative Criticism (London: SCM Press, 1999), 7. Our choice of narrative analysis as our exegetical method in this article is because Num 11:11-33 is a narrative text. Thus, Jean L. Ska correctly observes that, "like a good craftsman, the exegete does not first choose the instruments then the material on which to work. Rather, first, he inspects at length the material and only then, does he choose the instrument most adapted for the work he/she wants to realize." Jean Louis Ska, "Sincronia L'analisi narrativa," in Methologia dell' Antico Testamento (ed. H. Simian-Yofre; Bologna: 1994), 168. See also Meir Sternberg, The Poetics of Biblical Narrative: Ideological Literature and the Drama of Reading (Bloomington: Indiana University Press, 1985), 1.

9 "A reading from the perspective of Igbo-African woman" as used in this work refers to our decision in this work (rooted in the bosadi hermeneutics) to make marginalised African women the main hermeneutical focus of our reading of the Sotar ritual geared towards their liberation and empowerment. See also Madipoane Masenya, "A Bosadi (Womanhood) Reading of Genesis 16," Old Testament Essays 11/2 (1998): 271-287 (277).

10 Geographically, the Igbo people (Ndi Igbo) are located in the South-eastern Nigeria, West Africa. They occupy an area of approximately 15,800 square miles. See Victor Uchendu, The Igbo of Southeast Nigeria (Chicago: Holt, Rinehart and Winston, 1965), 3. Following the division of Nigeria into 36 states, Igbo people occupy Anambra, Imo, Enugu, Abia, Ebonyi, part of Delta, Cross-river, Rivers and Akwa Ibom states. The 2006 Nigerian census places the population of Igbo people at about 21 million. The majority of the Igbo people are Christians (about 80\%) while pockets of traditional religious practitioners spread throughout Igbo land. See Toyin Falola, ed., Igbo History and Society: The Essays of Adiele Afigbo (Trenton: African World Press, 2005), 141. 


\section{B A CRITICAL ANALYSIS OF NUM 5:11-31 AND ITS CONTEXTUAL IMPLICATIONS FOR THE CONTEMPORARY AFRICAN CONTEXT}

In this section, I will be guided by three questions targeted at understanding the gender asymmetry or otherwise of the entire Sotah ritual of Num 5:1 -31. (I) Why the Sotah ritual [vv. $11-14$ ]? (II) What is the process of Sotah ritual [vv. 15 -27]? (III) What are the consequences of the Sotah ritual for a guilty or for an innocent woman [vv. 27 -31]? In my reading, I will employ the bosadi hermeneutics to highlight the contextual implications of the Sotah ritual for a married Igbo (African) woman. ${ }^{11}$ The latter will be done by identifying and condemning some gender injustices found both in the Igbo-African culture and in the text of Num 5:11-33:

\section{Why the Sotah ritual [vv. $11-14]$ ?}

"The Lord spoke to Moses, saying (וידבר יהוה אל־משה לאמר): Speak to the Israelites and say to them (דבר אל בני ישראל ואמרת אלהם)" (Num 5:11-12). With these words commences the text of Num 5:11-12 and paints a picture of the entire ritual coming directly from YHWH's mouth to Moses. However, they should not be taken on the face value. Without disputing the revelatory nature of biblical laws and rituals, there is some consensus among scholars supported by clear biblical evidence that although biblical laws in the Pentateuch are directly or indirectly identified with Moses, they were not all given during his lifetime; they extended beyond him and their composition may have stretched over hundreds of years. ${ }^{12}$ According to Barr, they underwent a gradually development such that the mosaic legislation "came into existence over several hundred years, perhaps a thousand, rather than in two or three short bursts over a total forty-year period." ${ }^{13}$ Similarly, there is also a plausible scholarly view that biblical laws and rituals did not come out of nowhere. Their formulation is based on 'human situations' either intra-biblical [as narrated in biblical stories] $^{14}$ or extra-biblical [with reference to the concrete life of ancient Israelite/Judean people ${ }^{15}$ or laws/practices of other ancient Near Eastern

\footnotetext{
11 Masenya, "Struggling to Find "Africa" in South Africa."

12 James Barr, "Biblical Law and the Question of Natural Theology," in The Law in the Bible and in Its Environment (ed. Timo Veijola; Helsinki: Finnish Exegetical Society, 1990), 1.

13 Barr, "Biblical Law and the Question of Natural Theology," 9.

14 Calum M. Carmichael, The Origin of Biblical Law: The Decalogue and the Book of the Covenant (Ithaca: Cornell University Press, 1992), 2.

15 Barr belongs to this group and argues that biblical laws underwent developmental processes within which it is influenced by real human conditions and context. See Barr, "Biblical Law and the Question of Natural Theology," 2.
} 
neighbours of Israel, ${ }^{16}$ which begs the question, what informed the ritual for a 'suspected adulteress'? Why the Sotah ritual?

In answering this question, a brief allusion to the understanding and perception of adultery in the Hebrew Bible may be helpful. As I noted elsewhere, adultery ranks first among prohibited sexual offences in the Hebrew Bible and has both literal and metaphorical dimensions. ${ }^{17}$ The Hebrew Bible describes 'literal adultery' 18 as any consensual sexual intercourse between a married woman and any man not her husband. ${ }^{19}$ While the ban on adultery appears unbiased in terms of gender, there is an undue emphasis on the marital status of the adulteress (woman), a fact that highlights the Hebrew biblical patriarchal tendency.

There are four vital marks or elements for determining literal adultery in the Hebrew biblical laws. ${ }^{20}$ First, the woman involved must be married or at least be betrothed to a man. Thus, in as much as the woman 'belongs' to another man, any voluntary sexual intercourse with a third party is adultery. Secondly, for sexual intercourse between a married woman and another man to be termed adultery, there must be sexual intercourse (and penetration). This is suggested by the laws of Deut 22:25-27 on a raped betrothed virgin. Thirdly, the intercourse in question must be consensual (Deut 22:24, 25-27). The implication is that any sexual intercourse of a married woman with a third party done under duress is not adultery. Fourthly, for the culprits of adultery to be condemned to death according to biblical law, they must be caught in the act by some witnesses. To this end, the root מצא (especially in the niphal [to be found or caught] $)^{21}$ is used in many biblical adultery laws prescribing the death sentence for the culprits (Deut 22:22, 23-24, 25-27). Therefore, the testimony of two or three witnesses is required before condemning a person to death for adultery (Deut 17:6).

The question then is since at least two witnesses are required for condemning a culprit of literal adultery to death, how do we resolve a case of suspected adultery? What happens when adultery takes place in secret, when there are no human witnesses? In a sense, the Sotah ritual of Num 5:11-31, by

16 Bruce Wells, "What Is Biblical Law? A Look at Pentateuchal Rules and near Eastern Practices," Catholic Biblical Quarterly 70/2 (2008): 242.

17 See Alexander Abasili, The Understanding of Adultery in the Hebrew Bible: A Critical Survey (Dartford: Xlibris, 2016), 332-337.

18 The semantic field of נאף (adultery) in the Hebrew Bible could be split into three: (a) literal adultery, (b) metaphorical adultery and (c) political adultery. See Alexander Abasili, Marriage and Adultery in the Old Testament: An Igbo-African Contextual Reading (Hamburg: Verlag Dr. Kovac, 2018), 460.

19 Abasili, Marriage and Adultery in the Old Testament, 460.

20 For further reading, see Ibid., 464-466.

21 BDB, 594. 
presenting a ritual for resolving a case of suspected adulteress (סוטה) lacking human witnesses, fills this gap. It is, in this sense, unique from other laws of adultery in the Hebrew Bible (Lev 18:20; Deut 22:22-24).

Does the Sotah ritual, however, favour or disadvantage a suspected adulteress? In answering this question, the scholarly opinion is divided. Some commentators such as Joseph Milgrom and Galpaz-Feller argue that it is geared towards protecting the woman from her "husband's jealousy" and its inimical consequences like been 'lynched' and killed by her husband and others. ${ }^{22}$ Ironically, this apparently positive reason for the Sotah ritual is, at a deeper level, negative because it hints at the weak position of women in the patriarchal Israel society which makes them susceptible to such an unwarranted mob execution and in need of a Sotah ritual 'protection.' Other commentators see the ritual as an unnecessary torture inflicted upon a married woman rooted in the husband's irrational jealousy and only serves his selfish interest. ${ }^{23}$ For A. Philip, the emphasis on protecting a child's paternity and guaranteeing the legitimacy of a man's heir could have informed the lopsidedness of the Sotah ritual. ${ }^{24}$ In this regard, the grave punishments for a guilty adulteress serve as deterrent to other women about the deadly consequences of adultery in the Hebrew Bible. ${ }^{25}$ One cannot avoid the conclusion that the Sotah ritual highlights the unjust perception of adultery in this part of the Hebrew Bible almost as only a woman's transgression.

The text of Num 5:11-31, in my opinion, presents us with two related cases. Firstly, there is the case of a woman who actually indulged in adultery. The author's extra emphasis on this point is seen in his dedication of three and half verses out of his four introductory verses to the theme of a woman who secretly defiled herself by committing adultery $(5: 12-14 \mathrm{a})$ though 'she has not been caught.' The expression לא נתפשה 'she has not been caught' (v.13b) suggests that her crime was discovered by neither her husband nor any other witness. It is a situation where the required two or more witnesses needed for legally prosecuting and condemning an adulteress to death are lacking (see Deut 17:6).

The second case addressed by the Sotah ritual is a situation where the woman is innocent but is suspected and accused by her jealous husband of

22 Joseph Milgrom, "The Case of Suspected Adulteress" in The Creation of Sacred Literature (ed. Richard Freidmann; Berkley University of California Pres, 1981), 6975. See also Galpaz-Feller, "Private Lives and Public Censure," 159.

23 Johanna Stiebert, Violence in Marriage: A Closer Look at Numbers 5, 20 May 2019, https://www.shilohproject.blog/violence-in-marriage-a-closer-look-at-numbers$\frac{5 /}{24}$

$\overline{24}$ Anthony Phillips, “Another Look at Adultery,” JSOT 20 (1981): 7.

25 Susanna Clare Towers, "An Analysis of Philo's Exegesis of the Sotah Ritual," Women in Judaism 11/1 (2014): 6. 
having indulged in adultery - "if a spirit of jealousy comes on the husband, and he is jealous of his wife, though she has not defiled herself' (5:14b). This second reason for the Sotah ritual, rooted merely in the husband's irrational jealousy over his wife, underlines its unjust nature and lopsidedness against women. In a sense, the existence of the Sotah ritual legitimises and encourages a husband's suspicious demeanour against his wife leading to her public humiliation. Unfortunately, "there is no parallel text that considers a man's turning, a soteh, and a woman's jealousy. The text begs the question, why is there such a preoccupation, even cruel obsession, with women's fidelity?"26 The Sotah ritual is simply gender asymmetrical against women.

Since there are no human witnesses in both aforementioned cases to testify for or against the woman accused of adultery, the only reliable opinion in such a situation are the words of the accused woman. Unfortunately, her words cannot withstand the weight of a husband's jealousy in a patriarchal biblical context where men are at the centre of the stage. Therefore, recourse must be made to $\mathrm{YHWH}$, the highest legal authority in biblical Israel. ${ }^{27}$ Consequently, the complaint of the suspected woman's husband will be brought to YHWH in the Temple. The parallel between the Sotah ritual and the heifer ritual of Deut 21: 1-9 (a ritual for solving a case of an unresolved homicide) also supports the reading that non-availability of witnesses is the reason for bringing the case to YHWH in the Temple before the priest.

Notably, a husband initiates the Sotah ritual process by taking his wife to the temple. It is his "spirit of jealousy" founded or unfounded that actually sets the entire Sotah ritual in motion (v.14). Clearly, a husband's legal power and right over his wife's sexuality and not vice versa is underlined - a clear case of gender-asymmetry against women. According to Bonna Devora Haberman, "one purpose of the ritual is to diffuse male jealousy, which in many cultures throughout the world has wreaked and continues to wreak unmitigated violent punishment of suspected and not even convicted adulteresses." 28

Turning to the Igbo-African context, we note that the aforementioned patriarchal Hebrew Bible's tendency to concentrate legal rights in matters of sexuality in the hands of men and to perceive adultery almost as only a married woman's sin is also seen in some contemporary patriarchal societies. Igbo (African) culture is an example. Due to their family rootedness and community orientation, Igbo people treat adultery with seriousness. Just as marriage in Igbo culture is a covenant of affinity linking a family, clan and lineage to

26 Bonna Devora Haberman, "The Suspected Adulteress: A Study of Textual Embodiment," Prooftexts 20/1\&2 (2000): 15.

27 Hilary Lipka, Sexual Transgression in the Hebrew Bible (Sheffield: Phoenix Press, 2006), 105.

28 Haberman, "The Suspected Adulteress," 16. 
another, so is adultery which may lead to divorce and thereby rip the family and the extended family apart. Adultery is an agent of family disintegration with destructive consequences for a family-oriented people like the Igbo. It is, therefore, understandable that adultery is branded alu (pollution) in Igbo land. $A l u$, for the Igbo people, refers to ritual dirt which poses real danger to the well-being of the culprit, his or her family and relatives. Alu is also contagious and transferable to one's family and close friends. One can incur such ritual dirt through adultery. Adultery, for most Igbo Christians, ranks first among all the "offences against the dignity of marriage," hence, it is 'absolutely' forbidden. ${ }^{29}$

In principle, the prohibitions of adultery in Igboland apply equally to a married man and woman but in reality and in praxis, almost only married women bear the brunt of the ban. This almost one-sided perception of the ban on adultery as only a woman's problem in Igbo culture is clearly unjust and the patriarchal nature of Igbo culture provides a context for it. Some cultural reasons, which though cannot justify the sexual injustice against women, have been adduced for this gender inequality: (i) In Igbo land, there is a cultural belief that a woman's adultery opens up the possibility of having 'foreign' blood (spurious offspring) in the lineage. ${ }^{30}$ Indeed, the fear of spurious offspring in Igboland (and Nigeria) is so strong that it is enshrined in Nigeria's family law. The law states that a woman who is pregnant at the time of marriage for any man other than her newly wedded husband risks having the marriage voided at the instance of her husband. ${ }^{31}$ (ii) Since Igbo society is patrilineal and inheritance goes through the male line, a woman's adultery which produces a child not only disrupts and corrupts the lineage 'purity' but also 'steals' from the legitimate children the inheritance that duly belongs to them. (iii) In some parts of Igbo land, a woman's adultery is believed to cause contagious pollution with some serious consequences for both the culprit and her husband's family. (iv) Since Igbo people accept and practice polygamy, especially polygyny, women are 'accustomed' to sharing their husbands with other women but not the reverse. ${ }^{32}$ In other words, the century-long practice of polygamy may have made it culturally less repulsive for men to indulge in extra-marital sex with 'other' women. I must add immediately that the aforementioned cultural reasons cannot justify the one-sided perception of adultery in praxis as only a woman's sin.

In Igbo customary law, adultery is treated as a case of theft committed against the husband of the adulteress because it is tantamount to stealing his most precious 'possession' from him. In contrast, "a man convicted of adultery

29 CCC no. 2380.

30 Edwin I. Nwogugu, Family Law in Nigeria (Ibadan: Heinemann, 2006), 106.

31 Nwogugu, Family Law in Nigeria, 106.

32 Uchendu, The Igbo of Southeast Nigeria, 49. 
simply pays the prescribed compensation to the husband of his accomplice." 33 One cannot avoid the conclusion that adultery is treated as a woman's sin in Igbo culture. Surely, this smacks of sexual injustice against married women in a patriarchal society and it is unacceptable.

We now return to Num 5:11-33 to explore the process of the Sotah ritual.

\section{What is the process of the Sotah ritual [vv. 15 -27]?}

In the Sotah ritual, the 'jealous husband' brings his wife to YHWH in the Temple. He presents her to the priest with small quantity of barley flour, which he is instructed not to mix with oil or frankincense because it is "a grain offering of jealousy" (v.15b). As Lipka notes, "this identification of the offering with jealousy, the motivating force behind the proceedings that are to follow, perhaps explains why it is the husband who brings the offering, and not the wife, who later presents it before YHWH." ${ }^{34}$ When the husband and his wife arrive at the temple, the priest takes over the proceedings (vv.17-22). The priest mixes holy water with dust from the tabernacle floor in an earthen vessel to produce the water of bitterness. After dishevelling the hair of the woman, he will place in her hands the grain offering of jealousy and present her to YHWH. With the water of bitterness in his hands, the priest makes the woman take an oath of curse before YHWH. If the woman is innocent of her husband's accusation of marital infidelity, the oath will vindicate her and "she shall be immune and be able to conceive children" $(5: 28)$. However, if she is found guilty of adultery, the consequences are grave - the Lord will make her an execration and an oath among her people because her uterus will drop and her womb discharge issues (5:27). It is striking, says Bartor, that the woman whose fate is at stake is not allowed to present her own side of the story. After the whole long ritual, she is only permitted "a laconic utterance: "Amen Amen""35 _ an utterance that signals her unconditional acceptance of the ritual. The Sotah ritual concludes with the woman drinking the 'water of bitterness' "having written these curses on a scroll and washed them off in the water the priest will make the woman drink the water of bitterness" (v. 25).

The ritual ends with the statement: "The man shall be free from iniquity, but the woman shall bear her iniquity (v.31)." What does that mean? According to the rabbinic tradition, "the husband should not feel guilty if the wife dies, and he should not say, 'woe to me, for I have put an Israelite woman to death. Woe is me, for I have caused humiliation of an Israelite woman. Woe is me for

33 Nwogugu, Family Law in Nigeria, 241.

34 Lipka, Sexual Transgression in the Hebrew Bible, 105.

35 Bartor, Reading Law as Narrative, 112. 
I used to have sexual relation with a woman who was in fact unclean." $" 36$ Certainly, this rabbinic interpretation fits well, if the woman is found guilty; but what if she is indeed innocent? In such a situation, what is the implication of "the man shall be free from iniquity, but the woman shall bear her iniquity?" (v. 31). For Gray, it implies that "the man is, in any event, even if the ordeal proves his suspicion unfounded, free of guilt; the woman can be proved guilty." ${ }^{37}$ In other words, it is a law for the punishment of unfaithful women and not for reprimanding mistrusting men. One wonders why there is no penalty for a man when his accusation against his wife is unfounded. A punishment, no matter how slight, would have deterred men from unnecessarily subjecting their wives to this difficult ordeal of drinking bitter water which exposes them to public ridicule. Put differently, why is this law not applicable to men? Why could not a woman who also suspects her husband of marital infidelity subject him to a similar ordeal of bitter water? Certainly, this lopsided approach to suspected adultery is anything but just. In the Sotah ritual, only the woman has an obligation to sexual fidelity and no rights or powers. She must preserve her sexuality for her husband but cannot make the same claim on him.

We turn to the contemporary context. As in case of the Sotah ritual, men in some contemporary patriarchal societies also enjoy some lopsided legal rights over their wives and not vice versa. In Igbo culture, for instance, a wife is perceived as 'belonging' to her husband who paid the bride-price to marry her and whose name she bears and perpetuates through her children. It is a man that marries a woman into his house, clan and lineage and not vice versa. This tilts the pendulum traditionally in matters of rights and privileges in favour of men. The leadership of the society and the family are in the hands of men. During the family, kindred and village meetings, men constitute the assembly and take decisions on matters presented for deliberation. ${ }^{38}$ In cases of marital problems, women are usually at the receiving ends of the blame. Often and for various reasons, it is men who present their wives for punitive measure before the extended family and kindred. Even on rare occasions where courageous women report their guilty husband to the family due to sexual infidelity, the odds of success for the women are thin. Moreover, in the traditional Igbo society, it is seen as an insult to accuse a man of sexual misbehaviour in the face of his wife. Therefore, unlike a suspected or guilty wife who is openly reprimanded in the extended family and kindred assembly, a guilty husband would be reproached only by the elders and only in private. In cases of divorce or separation of married partners resulting from marital infidelity and other

\footnotetext{
36 Jacob Neusner, Sifre to Numbers: An American Translation and Explanation (vol.

1; Atlanta: Scholar Press, 1986): 747.

37 Gray, A Critical and Exegetical Commentary on Numbers, 56.

38 Joseph T. Agbasiere, Women in Igbo Life and Thought (London: Routledge, 2000), 38-39.
} 
reasons, the woman is always at the receiving end of the punishment - she is the one who moves out of the man's house leaving behind her children. ${ }^{39}$

Culturally speaking, there is also no special place in Igbo society for wives who because of marital problems are separated from their husbands. As such, some women who would have opted out of their unhappy marriage may prefer to remain in it and carry their cross than subject themselves to a cultural limbo in Igbo society through marital separation or divorce. Like the innocent victim of a Hebrew biblical Sotah ritual, the plight of such married African women often goes unnoticed as they suffer in silence. We condemn such injustice against women in a patriarchal society as unacceptable.

Turning to Num 5:11 -33, we now explore the implications of the Sotah ritual for a female victim.

\section{What are the consequences of the Sotah ritual for a guilty or an innocent woman [vv. $27-31]$ ?}

A closer look at both the reward for an innocent woman accused of adultery and the punishment for an adulteress is revealing. If the woman is innocent of her husband's accusation of adultery, the oath will vindicate her and "she shall be immune and be able to conceive children" (5:28). However, the consequences of the Sotah ritual for a guilty woman are grave: "the water that brings the curse shall enter into her and cause bitter pain, and her womb shall swell, and her thigh shall fall away, and the woman shall become a curse among her people" (5:27).

The exact meaning of the first curse, וצבתה בטנה ונפלה ירכה (and her womb shall discharge, her uterus drops [v.27]) and its implications, is debated among scholars. This is because the qal of צבת ( צבתה [to swell ) and its hiphil are attested only in this chapter without parallel in other Hebrew biblical books, thus, making their exact denotation difficult to grasp. ${ }^{40}$ There is much to recommend about Levine's suggestion that to understand the meaning and implication of the curse (her womb shall discharge and her uterus drop), recourse must be made to the outcome of the curse when the woman is innocent. ${ }^{41}$ Therefore, if the woman's reward for being innocent is her ability to conceive, retain her seed and bear children, ${ }^{42}$ then her punishment will be the reverse, "the termination of pregnancy by what amounted to an induced

\footnotetext{
39 Abasili, Marriage and Adultery in the Old Testament, 341.

40 BDB, 839. See Baruch A. Levine, Numbers $10-20$ (The Anchor Bible; London: Doubleday, 1993), 198.

41 Baruch, Numbers 10-20, 198.

42 Jacob Neusner, Sifre to Numbers: An American Translation and Explanation (vol. 1; Atlanta: Scholar Press, 1986), 121.
} 
miscarriage or abortion." 43 Within the context of biblical Israel, notes Gaebelein, this is a grave punishment because "for a woman in the ancient Near East to be denied the ability to bear children was a personal loss of inestimable proportion. It was in bearing children that a woman's worth was realized." 44

The second curse says, "and the woman shall become an execration among her people." The implication is that an adulteress will lose her honour in the society and die a social death caused by shame. As John Pilch notes, shame and honour belong to the central or core value of Hebrew biblical culture. ${ }^{45}$ Honour, according to Pilch is "a person's or group's claim to worth accompanied by public, social, acknowledgment of that worth." 46 In this connection, the abhorrent punishment received by a guilty adulteress will become a social deterrent to all married women in the community about the danger of adultery. Thus, "in the case of an oath, people will take an oath by her, saying, "May what happened to her happen to you." 47 However, does the fact of using the punishment of an adulteress as a warning to other married women about the nefarious consequences of adultery weaken the sexual injustice inherent in the Sotah ritual? The answer is no. I agree with authors who argue that the ritual "is likely to cause a woman great distress." 48 Clearly the dragging of an innocent woman to the temple, dishevelling of her hair and making her drink the "bitter water" constitute a real damage to her honour, and physical and mental health.

This brings us back to the Igbo-African context and the unfortunate sexual injustice suffered by some married women, a fact which bosadi hermeneutics encourages us to identify and condemn. The damage done to the honour of an innocent suspected adulteress in the Sotah ritual parallels in a sense that of an innocent Igbo-African married woman accused publicly by her husband of a bad moral behaviour - especially when she is innocent. Against the background of the community orientation of Igbo moral and ethical code, one's bad moral and ethical life is perceived as leading to social ridicule and shame which destroys one's reputation. Just as a person's morally and ethically good life brings joy and pride to the entire extended family and clan, so does a depraved moral life bring shame not only to the perpetrator but also to his family and clan. Therefore, to accuse an innocent woman publicly of sexual infidelity in Igbo society will inflict an irreparable damage on her social

43 George Buchanan Gray, A Critical and Exegetical Commentary on Numbers (The International Critical Commentary; Edinburgh: T\&T Clark, 1965), 53.

44 Gaebelein, Genesis-Numbers, 747.

45 John J. Pilch, Introducing the Cultural Context of the Old Testament (New York: Paulist Press, 1991), 52.

46 Pilch, Introducing the Cultural Context of the Old Testament, 52.

47 Neusner, Sifre to Numbers, 119.

48 Stiebert, Violence in Marriage, 7. 
reputation-which is tantamount to 'killing' such a woman socially. Unfortunately, some women in the patriarchal Igbo culture still endure such unwarranted social ridicule in the hands of their husbands.

\section{CONCLUSION}

In concluding this essay, we will underline the need to use a specific hermeneutic in reading 'oppressive' biblical texts and also point out the contextual implications of the Sotah ritual for a married Igbo-African woman.

\section{Need for specific reading lens and hermeneutic in interpreting Sotah ritual and similar 'oppressive' biblical texts}

Our reading of Num 5:11-31, using the bosadi biblical hermeneutics, has revealed the gender asymmetrical nature of the Sotah ritual to the detriment of women. Since the Bible is both oppressive and liberative, my reading of Num 5:11-31, rejected and condemned the sexual injustice and gender inequality contained in the Sotah ritual. In reading a biblical text like Num 5:11-31, which contains some 'oppressive elements,' this essay calls for a reading lens/biblical hermeneutic (like the bosadi) that clearly identifies both 'liberating elements' and 'oppressive elements' contained in them. Such reading lenses should reject the 'negative' and 'subjugating elements' seen in some biblical texts and at the same time emphasise the liberating and empowering roles of the Bible as the "Word of God" for all. Such an approach, among others, is meant to prevent the use (and abuse) of the Bible as an instrument of subjugation, and for resolving the dilemma of how biblical texts that are thoroughly patriarchal can still be seen as the inspired "Word of God." Most parts of the Bible contain both 'inclusive' and 'exclusive' dimensions. This, among others, is because the Bible is the "Word of God" in human language. ${ }^{49}$ Like everything that pertains to human being, the Bible also contains some imperfect elements. Thus, in spite of the divine inspiration of the Scriptures, its contents are not perfect. This explains the existence of both 'inclusive' and 'oppressive' elements in the Bible.

For an African contextual biblical interpretation, the bosadi biblical hermeneutics is a good biblical reading lens that builds on the continued vital role played by the Bible as the "Word of God" in the life of many Africans especially women. Its focus on the liberation and empowerment of women using the liberating and empowering qualities of the Bible is remarkable. It is a

49 As the Pontifical Biblical Commission explains, "The respective biblical writing comes from God through its author's living faith in God and through the relationship of this author with a specific form (or with different forms) of divine revelation." See Pontifical Biblical Commission, The Inspiration and Truth of Sacred Scripture: The Word That Comes from God and Speaks of God for the Salvation of the World (Collegeville, Minnesota: Liturgical Press, 2014), 10. 
reading lens that approaches the Bible with hope, with a view to transforming the oppressed by its liberative power. ${ }^{50}$

Our contextual bosadi reading of Num 5:11-33 argues that no ritual or biblical pericope should be used to justify the unfair treatment of any human being especially women. Indeed, the Bible as the "Word of God" should be a veritable instrument for empowering and liberating women and for fighting sexual injustice and gender inequality against women in patriarchal contexts.

The following are other contextual implications of the Sotah ritual for a married African woman.

\section{Perception of adultery as only a woman's sexual transgression is unacceptable}

The Sotah ritual is a clear case of gender asymmetry against women in the treatment of adultery in the Hebrew Bible. It is a ritual which forces a suspected adulteress to swear before YHWH (Num 5:11-31). Since there is no equivalent ritual for a suspected male adulterer, men apparently are exempted from such an oath. By implication, it is a ritual for the punishment of married women (whether guilty or not) but not for unfaithful married men. It begs the question: Why is there no punishment for a husband especially when his accusation of adultery is unfounded and merely based on irrational jealousy? A punishment of whatever kind would act as a deterrent to men who needlessly subject their wives (especially when innocent) to this difficult and dehumanising ordeal of the "bitter water" and exposing them to public ridicule.

As bosadi hermeneutics highlights, the Bible as "Word of God," is believed to have power to change situations positively in favour of all the oppressed including women in patriarchal cultures. It should be liberative to all and not oppressive. Therefore, the bosadi approach encourages us to reject oppressive biblical texts and to maximise the benefits of liberative biblical text for extending liberation and justice to all. While I reject the aforementioned 'oppressive elements' of the Sotah ritual, I immediately add that the central and core message of Hebrew Bible's attitude to marriage and adultery transcends them and points towards an inclusive and just world characterised by gender equality and justice for all. A good example of the core message of the Hebrew Bible's attitude to adultery is the Decalogue's לא תנאף - לא not commit adultery" (Exod 20:14//Deut 5:18). This apodictic law, on behalf of YHWH, prohibits adultery by all married men and women. Apart from its occurrence in the Decalogue, the greatness of this law also consists in its

50 Madipoane Masenya, "An African Methodology for African Biblical Sciences: Revisiting the Bosadi (Womanhood) Approach," Old Testament Essays 18/3 (2005): 741-750 (748). 
apodictic nature, which imbues it with a universal appeal and applicability. Unlike other biblical laws of adultery, it does not specify any particular punishment for the culprits of adultery. One might argue that it leaves it open because it does not want to get into specifics; it simply gives an imperative do not commit adultery!

I fully agree with Weinfeld's characterisation of this law as a categorical imperative of worldwide validity, transcending its original time and context. ${ }^{51}$ In other words, it points beyond its primary addressees (the ancient Israelites) and challenges the contemporary married Igbo-African people and the future community of believers to avoid committing adultery. It is a ban that applies equally to both married men and women indiscriminately - no gender is disadvantaged. Thus, the patriarchal tendency that paints a picture of adultery as a woman's sin is questioned and rejected by this Hebrew Bible's core message and egalitarian attitude to adultery. Put succinctly, the core message of the Hebrew Bible's perception of adultery is that men and women are equally bound by the prohibition of adultery. In this prohibition, there is neither man nor woman - all are equal under this law.

\section{Parallel between the dehumanising nature of the Sotah Ritual and the unjust punishment of women in patriarchal cultures}

To a suspected adulteress, the Sotah ritual is physically, socially, morally and psychologically dehumanising in nature. Even mere jealousy or hatred qualifies as a reason for a man to subject his wife to the ritual. As part of the ritual process, her hair will be dishevelled and she will be made to drink a 'bitter water' - a dirty concoction consisting of holy water, dust from the tabernacle floor and water used for washing the scroll. Even if a woman is innocent, the mere fact of going through this ordeal constitutes a truly dehumanising punishment and health risk (she could become ill from drinking this dirty water). Her social image, her reputation and honour will never remain the same after the ritual. Worse still, the suspected adulteress, though at the centre of the whole ritual, is rendered speechless in the entire Sotah ritual. She is only allowed to accept the ritual unconditionally at the end by saying, "Amen Amen."

In a sense, the 'bitter water' of Num 5:11-31 becomes a metaphor for the 'bitter' but often 'silent' social and sexual injustices endured by some married women in some patriarchal societies. We challenge and reject such gender injustices. The patriarchal inclination that makes women speechless and powerless in matters that affect them is rejected by Article One of the Universal Declaration of Human Rights - "All human beings are born free and

51 Moshe Weinfeld, Deuteronomy 1 -11 (The Anchor Bible 5; New York: Doubleday, 1991), 313. 
equal in dignity and rights." Hence, the gender difference in expectations, rights, rewards, duties and obligations of married couples in patriarchal African society (and other parts of the world) which tilts in favour of men are unacceptable, a fact made abundantly clear by the bosadi biblical hermeneutics. The rendering of women speechless in matters that pertain to them as seen in most patriarchal society are deplorable cases of gender inequality and injustice.

\section{Patriarchy should be replaced with egalitarianism}

That the Hebrew Bible is written against a patriarchal background where fathers and husbands enjoy disproportionately large legal rights and powers to the detriments of women is largely undisputed among biblical scholars. The Sotah ritual of Num 5:11-31 is a product of the Hebrew Bible's patriarchalism. It is a tendency that gives men legal power and right over their wives and their sexuality but not vice versa. The reality of these oppressive elements, if not critically questioned and rejected, makes the Hebrew Bible a double-edged sword susceptible to both liberative and oppressive use. The moral and ethical danger, for instance, is that the subordination of women in patriarchal societies could draw legitimacy from such Old Testament texts, which will make the text a partner in the perpetration of injustice. The bosadi approach succeeds in enabling these women to read the Bible in a way that affirms them.

Bosadi biblical hermeneutics calls for the reading on the Bible in a way that does not subjugate but affirm and empower women. Consequently, we condemn and reject the patriarchal tendency of the Hebrew Bible and support today's clarion call for gender equality, equity, justice and women's empowerment. Patriarchy should be jettisoned and egalitarianism and justice be promoted in society such that married men and women enjoy equal rights and obligations. Indeed, the asymmetrical treatment of adultery as only a married woman's sin in Igbo culture (and in some patriarchal African cultures) is a clear case of sexual exploitation of women, gender inequality and sexual injustice. The Sotah ritual cannot be used to support such an oppressive and exploitative practice. Such Old Testament texts should in no way be used to exploit others and to subjugate women. Instead, they should be read in a specific way and with particular biblical hermeneutical approaches (such as bosadi) that foster the attainment of God's desire for humanity which includes a just and inclusive society for everyone.

\section{BIBLIOGRAPHY}

Abasili, Izuchukwu Alexander. Marriage and Adultery in the Old Testament: An Igbo-African Contextual Reading. Hamburg: Verlag Dr. Kovac, 2018. . The Understanding of Adultery in the Hebrew Bible: A Critical Survey. Dartford: Xlibris, 2016.

Adamo, David T. "The Task and Distinctiveness." Old Testament Essays 28/1 (2015): 31-52. 
. "What Is African Biblical Hermeneutics?” Black Theology: An International Journal 13/1 (2015): 59-72.

. "Reading Psalm 35 in Africa (Yoruba) Perspective." Old Testament Essays 32/3 (2019): 936-955.

Agbasiere, Joseph Therese. Women in Igbo Life and Thought. London: Routledge, 2000 .

Barr, James. "Biblical Law and the Question of Natural Theology." Pages 1-22 in The Law in the Bible and in Its Environment. Edited by Timo Veijola. Helsinki: Finnish Exegetical Society, 1990.

Bartor, Assnat. "Reading Law as Narrative: A Study in the Casuistic Laws of the Pentateuch." Atlanta: Society of Biblical Literature, 2010.

Brichto, Herbert Chanon. "The Case of the Sotah and a Reconciliation of Biblical Law." Hebrew Union College Annual 46 (1975): 55-70.

Brown, Francis, Charles A. Briggs and S.R. Driver. The Brown-Driver-Briggs Hebrew and English Lexicon of the Old Testament. Oxford: Clarendon, 1952.

Budd, Philip J. Numbers. Word Biblical Commentary 5. Waco: Word, 1984.

Chapman, Geoffrey, ed. Catechism of the Catholic Church. London: Cassell, 1994.

Carmichael, Calum M. The Origin of Biblical Law: The Decalogue and the Book of the Covenant. Ithaca: Cornell University Press, 1992.

Falola, Toyin, ed. Igbo History and Society: The Essays of Adiele Afigbo. Trenton: African World Press, 2005.

Friedman, Richard. "Why Is This Case Different from All Other Cases?" 371-382 in Let Us Go up to Zion: Essays in Honour of H. G. M. Williamson on the Occasion of His Sixty-Fifth Birthday. Vol. 153. Vetus Testamentum Supplements, 2012.

Gray, George Buchanan. A Critical and Exegetical Commentary on Numbers. The International Critical Commentary. Edinburgh: T \& T Clark, 1965.

Haberman, Bonna Devora. "The Suspected Adulteress: A Study of Textual Embodiment." Prooftexts 20/1\&2 (2000): $12-42$.

Jeon, Jaeyoung. "Two Laws in the Sotah Passage (Num. V 11 -31)." Vetus Testamentum 57/2 (2007):181-207.

Lawson, Annette. Adultery: An Analysis of Love and Betrayal. Oxford: Basil Blackwell, 1988.

Levine, Baruch A. Numbers 10 -20. The Anchor Bible. London: Doubleday, 1993.

Lipka, Hilary. Sexual Transgression in the Hebrew Bible. Hebrew Bible Monograph 7. Sheffield: Phoenix Press, 2006.

Maarsingh, B. Numbers: A Practical Commentary. Text and Interpretation. Grand Rapids, MI: Eerdmans, 1987.

Marguerat, Daniel and Bourquin, Yvan. How to Read the Bible: An Introduction to Narrative Criticism. London: SCM Press, 1999.

Masenya, Madipoane. A Bosadi (Womanhood) Reading of Genesis 16." Old Testament Essays 11/2 (1998): 271-287.

. How Worthy Is the Woman of Worth? Rereading Proverbs 31:10-31. New York: Peter Lang, 2004. 
- "An African Methodology for African Biblical Sciences: Revisiting the Bosadi (Womanhood) Approach.” Old Testament Essays 18/3 (2005):741 750.

Masenya (gwan'a Mphahlele), Madipoane. "Struggling to Find 'Africa' in South Africa: The Bosadi (Womanhood) Approach to the Bible." Society of Biblical Literature Forum, n.p. Cited August 2021. Online: http://sblsite.org/Article. aspx?ArticleID=402.

Metuh, Emefie Ikenga. Comparative Studies of African Religions. Enugu: Snaap, 1999.

Milgrom, Joseph. "The Case of Suspected Adulteress." Pages 69-75 in The Creation of Sacred Literature. Edited by Richard Freidmann. Berkley University of California Press, 2016.

Neusner, Jacob. Sifre to Numbers: An American Translation and Explanation. Vol. 1. Atlanta: Scholar Press, 1986.

Nwogugu, Edwin I. Family Law in Nigeria. Ibadan: Heinemann, 2006.

Okechukwu, Sylvanus. Christian Marriage and Genetic Engineering: A Dialogue. Owerri: St John, 2001.

Phillips, Anthony. "Another Look at Adultery." Journal for the Study of the Old Testament 20 (1981): 3-25.

Pilch, John J. Introducing the Cultural Context of the Old Testament. New York: Paulist Press, 1991.

Pontifical Biblical Commission. The Inspiration and Truth of Sacred Scripture: The Word that Comes from God and Speaks of God for the Salvation of the World. Collegeville: Liturgical Press, 2014.

Santos, Ricardo Fal-Dutra. "Challenging Patriarchy: Gender Equality and Humanitarian Principles." Cited 10 Nov. 2020. Online: https://blogs.icrc.org/law-and-policy/2019/07/18/gender-equalityhumanitarian-principles/.

Ska, Jean Louis. "Sincronia L'analisi narrativa." 139-170 in Methologia dell' Antico Testamento. Edited by H. Simian-Yofre. Bologna, 1994.

Stade, B. "Beiträge zur Pentateuchkritik." Zeitschrift für die alttestamentliche Wissenschaft 15 (1895): 157-266.

Sternberg Meir. The Poetics of Biblical Narrative: Ideological Literature and the Drama of Reading. Bloomington: Indiana University Press, 1985.

Stiebert Johanna. Violence in Marriage: A Closer Look at Numbers. 5 May 20, 2019. Cited 19 August 2020. Online: https://www.shilohproject.blog/violence-inmarriage-a-closer-look-at-numbers-5/.

Towers, Susanna Clare. "An Analysis of Philo's Exegesis of the Sotah Ritual." Women in Judaism 11/1 (2014): 1-24.

Uchendu, Victor. The Igbo of Southeast Nigeria. Holt, Richard and Winston, 1965.

Wells, Bruce. "What Is Biblical Law? A Look at Pentateuchal Rules and Near Eastern Practices." Catholic Biblical Quarterly 70/2 (2008): 223-243.

Weinfeld, Moshe. Deuteronomy $1-11$. The Anchor Bible 5. New York: Doubleday, 1991.

Dr. Alexander Izuchukwu Abasili, Biblical Studies Department, KU. Leuven. Pfarrgasse 1, D-93104 Riekofen, Deutschland. E-mail: alexabasili@yahoo.com. ORCID: https://orcid.org/0000-0001-8478-2545 